\title{
喉頭狭窄のＣＯ２レーザー治療
}

高須昭彦、岩田重信、桜井一生、岩田義弘

藤田保健衛生大学耳舅咽喉科

\section{CO2 Laser Surgery for Laryngeal Stenosis}

Takasu Akihiko, Iwata Shigenobu, Sakurai Kazuo, Iwata Yoshihi

Fujita Health University School of Medicine, Department of Otolaryngology

\begin{abstract}
Laryngeal stenosis has been difficult to be repair and numerous surgical procedures have been used to try to treat this disorder.

Thirteen cases with the laryngeal stenosis ( 8 with bilateral vocal cord paralysis ; BVCP and 5 with cicatricial laryngeal stenosis) were treated by micro carbon dioxide laser surgery including posterior partial cordectomy and incision and/or vaporization of the scar in our clinic during 5 years from 1992.

Twelve patients ( 8 with BVCP and 4 with cicatricial stenosis) achieved adequite airway and decannuration and subjectively good voice quality. Our only failure was in a patient with cicatricial glottic and subglottic stenosis.

The success of $\mathrm{CO} 2$ laser surgery for cicatricial laryngeal stenosis depends on re-epithlialization of the raw surface before scar formation.Therefore, epithelial coverage of the postoperative wound is an important factor in preventing restenosis.

We emphasized that technical development on the endoscopic transplantation of a free graft without stents or sutures has been expected for a significant therapeutic advance.

はじめに

喉頭㹨窄を来す疾患は腫瘍をはじめとして様々 な疾患が存在するが、慢性喉頭狭窄症のうち両側 声带麻㽻や声門部版痕性狭窄症は呼吸困難や発声 障害を訴え積極的な治療が必要である。

これら声門部狭窄症の外科的治療の目標は、気 道の確保之音声の保存という互いに相反する課題 を抱えるが、この目標を達成することは患者のQ

○ Lを高めるために重要である。

1992年から1996年9月までの約5年間に私たち の教室で声門部を中心とした狭窄症 13 例を経験 し、顕微鏡下にCO2レーザー治潦を行った。ここ では主に呼吸道の礁保の面から CO2レーザー治 療の今後の問題点を検討した。

\section{| 両側声帯麻瘏について}




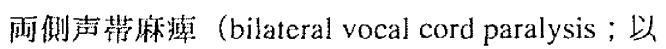
下BVCP と格す）は 8 例で、原因は甲状腺術後 3 例、交通外㑺 1 例、特発性 4 例である。症状は力 ニューレ报去困難を念めて呼吸困難が大部分であ るがその程度は様々であった（表 1）。

表 1

\begin{tabular}{|c|c|c|c|c|c|}
\hline 症例 & 年糙 & 性 & 原 因 & 主 訴 & その他 \\
\hline 1 & 29 & $M$ & 交通外儆 & 呼吸困醀 & \\
\hline 2 & 56 & $M$ & 特発性 & 喘＼cjkstart鳴 & \\
\hline 3 & 47 & $M$ & 甲状腺手術 & 呼吸困踓 & \\
\hline 4 & 66 & $\mathrm{~F}$ & 特発性 & 呼吸困雜 & \\
\hline 5 & 53 & M & 特発性 & いびき・睡眠障害 & \\
\hline 6 & 59 & $M$ & 特発性 & 㪕度呼吸困嚾 & \\
\hline 7 & 64 & $F$ & 甲状腺手術 & 力二1-庪去困踓 & \\
\hline 8 & 65 & $\mathrm{~F}$ & 甲状腺手郝 ${ }^{*}$ & 力二卫一抜去困難 & 声帯後部病著" \\
\hline
\end{tabular}

BVCPに対するCO2レーザーによる跍鬥後部 開大術は、Ossoff(1983年) Arytenoidectomy、Crumly ら(1989 年) Medial arytenoidectomy (以下 $\mathrm{mA}$ 亡 略す)、Dennis ら(1989年) Posterior partial cordectomy（以下 PPC と略す）、Kashima ら（1991 年） Transverse cordotomy (以下TCdoと略す)など 1980 年代から盛んに行われるようになった。

表 2 に当教室でのCO2レーザーによる非門後 部開大術の手術法と治挍成績を手術順に示した。 手術法は若干変化しており、初めの頃は初回手術 で片㓱の mAやPPCを行っていたが、術後に肉犽 や搬痕による再狭窄のため再手術を必要とした例 （症例 2・4）を経験したことから、当教室では術 後の呼吸機能の確保に重きを䈯いて声带突起直前 より前 $1 / 2$ 程度までの声带膜様部をレーザー切除 する Extended posterior cordectomy（EPC）を行っ ている。その後は再手術例は経験していない。

\begin{tabular}{|c|c|c|c|c|}
\hline 症例 & 手術法 & 気切 & 拔去 & 律後経過 \\
\hline 1 & rs. PPC & + & 0 & 意 好 \\
\hline 2 & Is. $m A \Rightarrow$ bi. PPC & & & 良 好 \\
\hline 3 & rs. EPC & + & 0 & 良好 \\
\hline 4 & rs. PPC $\cdot m A \Rightarrow$ Is. PPC & + & 0 & ときに喘鷍 \\
\hline 5 & rs. EPC & & & 液間咳椋 \\
\hline 6 & rs. EPC & & & 夜間咳濑 \\
\hline 7 & rs. EPC & + & 0 & 良 好 \\
\hline 8 & rs. EPC $\cdot m A+$ Is. TCdo & + & 0 & 良 好 \\
\hline
\end{tabular}

5 例に行われた気管切開孔は、4例は閉鎖され た。症例 8 はチューブを装着して入院し、術後 はそのまま退院したが、遠隔地であるため他院に
て报去され経過良好である。

呼吸に関する術後経過は、症例 4 でときに喘鳴 を訴え。症例 5,6で唾昨時の緊張低下による咽頭 分泌物の吸引と考えられる液間咳嫩を生じること があり今後長期の経過観察が必琶である。全体的 には讙燕の訴えは認めず、日常生活の活動性や、 音声もよく保たれており、良好な術後成績を得て いる。

\section{提示例 1}

症例番号 3 特発性 B V C P、56藏、男性。

初回手術で左に $\mathrm{mA}$ を行ったが、術後 9 ケ月頃 からふたたび呼吸困難を訴えるようになり、1 1 ヶ月後に雨側にレーザーPPCを追加した。2 回 目の手術以後は声閒後部の開大は良好で呼吸困難 は全く認めない。音声はやや弱いが不満は訴えて いない（図 1a,b)。

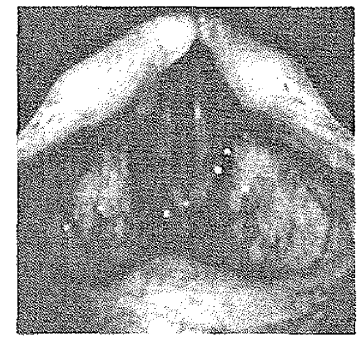

图 1 a 淮前発声時

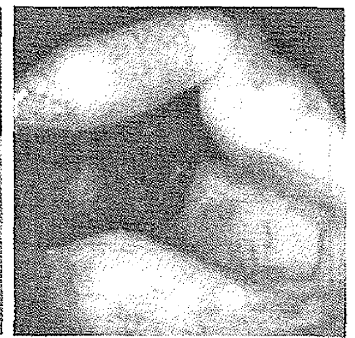

b 術後発声㘧時

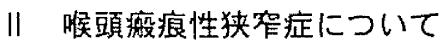

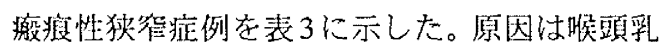
頭腫のレーザー術後3例、喉頭部分切除後 1 例、気 道熱賃 1 例であった。

\begin{tabular}{|c|c|c|c|c|c|}
\hline 站洌 & 年齿 & 性 & 原因 & 主謶 & 狭窄部位 \\
\hline 9 & 14 & $M$ & 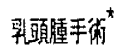 & 加-性去困墐 & 声門上·声門·声門下部 \\
\hline 10 & 16 & F & 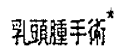 & 加上忮去困蜼 & 声門上·声門部 \\
\hline 11 & 71 & M & 娭頙部沏後 & 発声障害 & 声門部 (前交連部) \\
\hline 12 & 24 & $F$ & 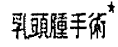 & 発声障害 & 声門部 (前交連部) \\
\hline 13 & 16 & $F$ & 気道熱偒 & 耑鳴 発声障害 & 声門部 (声帯膜核部全長) \\
\hline
\end{tabular}

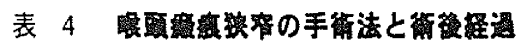

\begin{tabular}{r|l|c|c|c}
\hline 症例 & \multicolumn{1}{|c|}{ 手術法 } & 気切 & 力拔去 & 術後経過 \\
\hline 9 & Vaporization + Stent & $+^{*}$ & $\mathrm{X}$ & 治療中 \\
10 & Vaporization & $+^{*}$ & O & 良 好 \\
11 & Vaporization & & & 良 好 \\
12 & Cutting & & & 良 好 \\
13 & Cutting + Stent & & & 良 好 \\
\hline
\end{tabular}




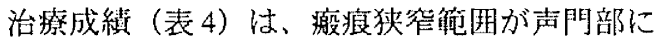
限局する例（症例 11・12）では, 膜状の㹨窄部を レーザー切除した。症例 13 （図2）はほぼ声带膜 様部全長に瘾着を生じていた。同部をレーザー切 除したが再瘑着を生じたため、2 回目の手術では レーザー切除後シリコンステントを留置すること で比較的短期間に治療可能であった。症例10では 頻回の手術を要したが、カニューレ报去が可能と なり経過良好である。

図 2

熱倠による声茾

膜様部の web

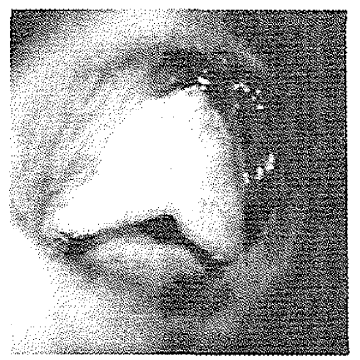

\section{提示例 2}

症例番号 9、16藏、男性、喉頭疫痕㹨窄症。

本例は喉頭の多発性乳頭腫のレーザー手術後に 呼吸困難を生じたため気管切開を施行され当科を 紹介された。

乳頭腫はすでにコントロールされていたが、䐅 頭鏡㭘査では㿂痕のため声带・仮声带などの本来 の形態は失われており、前後 $3 \mathrm{~mm}$ 、幅 $1 \mathrm{~mm}$ 程 度の小さな声門が観察されるに過ぎなかった。前 交連部および声門後部、披裂部は灕着して可動性 は著しく制限されていた（図3）。

\section{図3 右}

手術時喉頭所見

図 4 下

C T 所見 矢印は 病変部を示す
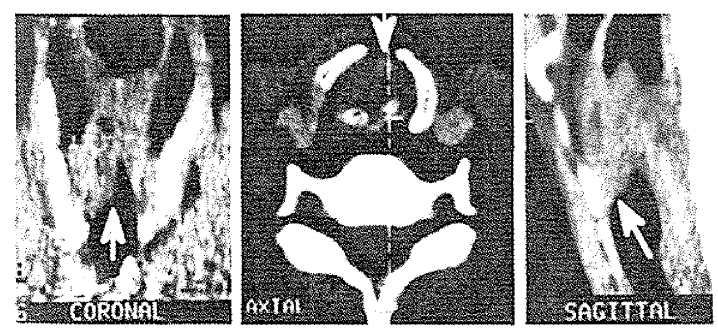

C T 検督では、甲状軟骨正中部の下 $1 / 2$ の欠 損や瘏痕拘絸による声門前後長の短縮が観察さ れ、聲門下前方に軟部㓌影の增加がみられた（図 4)。

本例に対して、喉頭の杵組み抎大を芳虑した経 皮的な一期的手術あるいは段階的手術も考慮され たが、患者の希望もあって先ず顕微鏡下レーザー 手術を試みた。

手術は声門の全面㵂着を避けるため洀痕痹着し た後交連部を保存したまま声門前方および声鬥下 前方の狭窄部にCO2レーザー照射して瘏痕組織 を蒸散させた。創部にはシリコンステントを留䁂 し前搷部皮店に固定した。4ケ月後にステントを 固定した前頝部皮底に謴瘍性のビランを生じ、湛 孔形成が危惧されたためステントを报去した。そ の後、声門は旅痕收維のため前後径が徐々に短く なり、術前に比べやや大きくはなったものの気管 孔を閉鎖するまでには至らず現在も治痽中であ る。

本例の術後再狭窄を生じた原因として、

1）CO2レーザーの㬎射は上方からの一方向に 限られるため、発声に必要な声門部形態を残そう とすると声門下の瘾痕切除が不充分になったこ と、2）気道として重姴な殸門後部を治㾐術野に 含めなかったことが主要な原因であり、2次的に は、3）蒸散させた後の術創の上皮化を図る手段 としてステント留䁂のみでは不充分であり、ステ ント抜去後に瘢痕収縮がさらに進行し気道として 充分な殸門部の前後長が得られなかったこと、な どが考えられた。今後は甲状軟骨枠組み形成や 粘膜移植などを含めた㬋䫓再建を考える必要があ ると思われる。

\section{考祭}

最近では頭钼部領域の諸病変に対するレーザー の䠦床応用は、種々のレーザー光の開発や応用技 術の発展と最小限の手術侵熋で患者の負担を㪕減 できる方法としてはますます重献な手術手段と なっている。垈頭病変におけるCO2レーザー の使用は Strong と Jakoの派告（1972 年）を嘴天 とするが、鏡視下CO 2 レーザー手術は手術操作 を行う空間が制限される管腔㖑器においても正碓 な手術手技が可能であることがその臨床的応用を 抎げている。従来、側方照射に難点があったが 
ファイバー導光の実用化やK T P レーザー装䁂の 出現などにより解決されつつある。

唉頭㹨窟症における呼吸道の挔大は重琶な手術 目標の一つである。B V C P に対する治療として 声带側方固定術（Woodman 1946）は基本的な治 筴法であったが外切開を必亚とする。現在では䫓 微鏡下CO2レーザー手術が主流を占め、良好な 成繥が報告されている。一方、搬痕性狄窄症は、 その狭窄の部位や程度がさまざまであり、特に装 門部を中心とした高度な狭窟症は治療に難㗪する ことが多い。

レーザー手術は照射箅囲の大小に拘わらず共通 している問題は、レーザーによって切除あるいは 蒸散された組織の修復過程における肉芽形成や結 合織の增生、または術後長期間にわたって生じる 創の瘷痕収緛などの術後性変化が抎大された気道 の再㹨窄や音声障害の原因となることである。し たがって気道の確保と音声の保存という手術目標 は術後性変化が予测される籍国内に留まるときに 達成されることになる。このような理由から最初 の創は大きめに切除されることが多い。

術後性変化を最小限にするために、B V C P で はCO2レーザーで切開・切除する位置や笵目につ いても様々な工夫がされているが、未だ確立した 方法はなく、熱練者の経験則に依っているところ が大きい。また、洀痕狄窄症においても同様であ る。

当教室症例の㭘討からも B V C P に刘するCO2 レーザーによる声带後部開大術は有用な方法と考 える。しかし、泎淖声带の位幒や運動障害の原因 などを考慮した術式の選択や術後性变化を最小限 にする補助的治撩法などを含めて長期予後の評牦 は今後の課題と考えられた。

洀痕性狭窟症の場合、webのような前交連を中 心とした膜状狭窄では CO2レーザーによる切除 とシリコンステントによって再癒着を防止しつつ 上皮化を促進して、気道㹡大を図る方法が有效で あるが、より広箍围で瘏痕の厚い例の上皮欠損に 刘して、有茎粘膜弁あるいは遊離粘膜弁移植が有 用であるが喉頭截開術を必姴とする。

喉頭内アプローチによって術後の粘膜火損創の 安定化を図り、上皮化を促進する方法として、比 較的小さな創に対するフィブリン接着剂の応用は 入手し易く使用している術者は多い。ステントと
してシリコン板、テフロンキール、Tチューブな どの利用は上皮化までに長期間を㼛することが難 点で、ときには長期留琶が困難であったり、声門 後部の形热に適合しないため堠頭では失敗するこ とを経験する。

提示例2に示したような高度な瘶痕㹨窄症では 声門前部および気道となる後部の抾大が必要とな るが、同時に上皮久損部の筑睍も広くなるため、 早期に上皮化を図る手段が重要となる。

後交連部㨨着、声門下洀痕㹨窄に対してDedo らは㾘痕部の粘膜上皮を保存しつつ、粘膜下疫症 をレーザー蒸散させ、残した粘膜弁で㓱面を被愎 する倁頭内アプローチによる micro trapdoor flap techniqueを報告している。披裂関節強直がなく声 門が比較的よく關いている場合（3-4mm）に有用 とされるが、技術的な困難さを伴う。

叫美頭アプローチによる粘膜移植の問題点は呼吸 特の移植糊膜弁の安定性と粘膜を仰展する技術の 困難さにあり、応用は望萃上面などの小範围の使 用に留まっている。Zhi Wangらは特殊な器具の 洘案と低出力レーザーによる接着技術によって遊 敖粘膜移植の实験的有用性を報告している。今 後、唝頭機能を若虙した顯微鏡下レーザー手術の 碑応を昖げるためには術創の上皮化を早期に完成 させることが重要な課題の一つ考えられ、より安 定した接着技術とともに管腔内に移植弁を伸展さ せる技術の開発などが望まれる。

\section{まとめ}

当教室における B V C Pおよび洀痕性㹨窄症の 症例检䛠からCO2レーザー手術後に安定した気 道を確保するためには術後㓱の上皮化を早期に図 る方法の開発が必要であることを強調した。

\section{参考文献}

1）村上 泰: 喉頭狭窟症。日気食 $41: 5,327$ $335,1990$.

2）佐藤公則、坂口伸治、他：堠頭・気管狭帘例の 臨床統計之治療.耳鼻際床 補62:77-85, 1993. 
3) Strong,M.S. and Jako, G.J.:Laser Surgery in the Larynx;Early Clinical Experience With Continuos CO2 Laser.Ann Otol Rhinol Laryngol, 81:791-798, 1972.

4) De Graaf Woodman, MD.:A Modification of the Extralaryngeal Approach to Arytenoidectomy for $\mathrm{Bi}$ lateral Abductor Paralysis. Arch Otolaryng 43:6365, 1946.

5) Robert H. Ossoff, MD., George A. Sisson, MD., et al.: Endoscopic Laser Arytenoidectomy for the Treat ment of Bilateral Vocal Cord Paralysis.

Laryngscope 94:1293-1297, 1984.

6) James A. Duncavage, MD and Leonard S. Piazza, MD.:The Microtrapdoor Technique for the Manage ment of Laryngeal Stenosis.Laryngoscope 97:825$828,1987$.

7) Donald P. Dennis, MD. and Haskins Kashima, MD.: Carbon Dioxide Laser Posterior Cordectomy of Bilateral Vocal Cord Paralysis. Ann Otol Rhinol Laryngol 98:930-934, 1989.

8）進 武幹：両側性反回神経麻瘨に対する音声 外科 J OHNS 9:5, 55-60, 1993.

9）平野 実：声带の運動障害とその音声外科的 治療 耳展 $37: 4,395-404,1994$.

10）大山腅，昇卓夫，他：両側反回神経麻 㳯のレーザー手術1. J OHN S $7: 10,113-117$, 1991.

11）米川紘子, 玉木克彦, 他 : 声門後部瘾着症 の治瘵経験。喉頭 4:46-51， 1992.

12）児嶋久剛, 大森孝一, 庄司和彦: 喉頭内腔 への粘膜移植とフィブリン糊の有用性. 耳率 $39: 265-266,1993$.

13) Herbert H. Dedo, MD.and C. Daniel Sooy, MD.: Endoscopic Laser Repair of Posterior Glottic, Sub glottic and Tracheal Stenosis by Division or MicroTrapdoor Flap.Laryngoscope 94:445-450, 1984.

14) Zhi Wang,MD;Michail M.Pankratov,MS;Elie E.Rebeiz,MD;et al: Endoscopic Diode Laser Weld ing of Mucosal Grafts on the Larynx: A New Technique. Laryngoscope 105: 49-52, 1995.

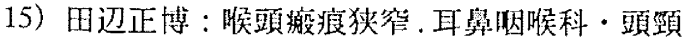
部外科MOOK $23: 55-61,1992$.

16）岩田重信, 高須昭彦, 桜井一生, 他：喉頭 外偳一外損傷の統計的観祭一。耳鼻 $40: 118$ -
133, 1992.

17）桜井一生, 岩田重信: 声門上型喉頭㹨窄の形 成術. J OHNS 10 : 8, 1129-1131, 1994. 